\title{
MENINGKATKAN KEMAMPUAN MENYIMAK ANAK KELOMPOK A USIA 4-5 TAHUN MELALUI METODE BERCERITA DI AL-HILAL MATARAM TAHUN PELAJARAN 2018/2019
}

\author{
Gustiati \\ TK Al-Hilal \\ gustiati28@yaho.com
}

\begin{abstract}
Abstrak. Penelitian ini di latar belakangi oleh kurangnya kemampuan menyimak anak di TK Al-Hilal. Adapun permasalahan yang diangkat dalam dalam penelitian ini adalah bagaimanakah bercerita yang tepat untuk meningkatkan kemampuan anak kelompok A usia 4-5 tahun melalui metode bercerita di TK Al-Hilal. Sedengkan tujuan yang ingin dicapai dalam penelitian ini adalah untuk mengetahui peningkatan kemampuan menyimak anak Kelompok A usia 4-5 tahun, jenis penelitian ini merupakan penelitian tindakan kelas, motode penilitian ini menggunakan Analisis deskriptif kualitiatif, subjek penelitian ini adalah kemampuan menyimak anak. Dari hasil analisis yang diperoleh pada siklus I dan siklus II, pada siklus I ada tiga anak atas nama sifa, fiqa dan ica Belum Berkambang 20.0\%, 11 anak Mulai Berkembang 73,3\%, 1 orang anak atas nama Sayid Berkembang Sesuai Harapan 6,7\% dan di katakan masih belum maksimal. Maka dilakukan siklus II dimana tahap ini hasil yang dicapai 1 orang anak atas nama Nayra Mulai Berkembang 6,7\%, 12 anak Berkembang Sesuai Harapan 80,0\%, 2 orang anak yaitu Via dan Fiqa Berkembang Sangat Baik 13,3\% dimana semua aspek pembelajaran meningkat yaitu semua anak mampu menyimak melalui metode bercerita.
\end{abstract}

Kata Kunci : Kemampuan, menyimak, Metode bercerita.

\section{PENDAHULUAN}

\section{Latar Belakang}

Pendidikan Anak Usia Dini adalah suatu upaya pembinaan yang ditujukan kepada anak sejak lahir sampai dengan usia enam tahun yang dilakukan melalui pemberian rangsangan pendidikan untuk membantu pertumbuhan dan perkembangan jasmani dan rohani anak agar memiliki kesiapan dalam memasuki pendidikan lebih lanjut. "Peraturan Menteri Nomor 58 Tahun 2009 pasal 1 angka 14.

Anak usia 4-5 tahun merupakan bagian dari anak usia dini yang disebut sebagai anak usia prasekolah. Pada masa ini banyak terjadi perkembangan dan pematangan fungsi otak, fisik dan psikis yang akan merespon stimulasi-stimulasi dari lingkungan sekitar.

Dalam lima tahun pertama yang disebut dengan The Golden Years (masa emas), seorang anak mempunyai potensi yang sangat besar untuk berkembang. Pada usia 4-5 tahun, volume otak anak $90 \%$ dari otak orang dewasa . Dimasa-masa inilah, anak mulai dapat diarahkan sesuai dengan tujuan yang diharapkan, dan sesuai dengan perkembangan yang diharapkan.

Masa Usia 4-5 tahun sangat berpotensi dalam mengembangkan semua aspek perkembangan dalam diri anak seperti, aspek perkembangan nilai moral dan agama, aspek perkembangan kognitif, aspek perkembangan bahasa, aspek perkembangan fisik motorik, dan aspek perkembangan sosial emosional. Dimana kelima aspek perkembangan tersebut saling menunjang satu sama lainnya. Salah satu kemampuan yang merupakan dasar dari semua proses komunikasi dari sejak lahir.

Kehidupan manusia diawali dengan tangisan sebagai bahasa pertama anak, dengan bahasa tersebut seorang bayi mengkomunikasikan segala kebutuhan dan keinginannnya. Beberapa ahli berpendapat bahwa anak-anak dilahirkan kedunia dengan perangkat perolehan bahasa yang membentuk kemampuan anak dalam mendeteksi 
gambaran dan aturan bahasa Chomsky (dalam Santrok, 2007: 370).

Perkembangan bahasa meliputi 4 bagian yaitu menyimak, kemampuan berbicara, kemampuan membaca, dan kemampuan menulis. Pemahaman tentang karakteristik perkembangan bahasa anak secara natural diperlukan dalam rangka memberikan berbahasa yang tepat pada anak yang sesuai dengan kebutuhannya.

Salah satu bagian dari perkembangan bahasa yaitu menyimak. Menyimak dalam kegiatan komunikasi sehari-hari memiliki peranan yang sangat penting, karena dengan menyimak kita dapat memperoleh informasiinformasi untuk menambah wawasan, pengetahuan dan pengalaman tentang kehidupan. Begitu pula dalam konteks pembelajaran menyimak memiliki peranan yang sangat potensial bagi peserta didik. Dengan menyimak maka peserta didik dapat menambah pengetahuan menerima dan menghargai pendapat orang lain. Oleh sebab itu untuk dapat memiliki tingkat kemampuan menyimak maka diperlukan latihan-latihan menyimak secara intensif (Subyakto, 2005:18).

Berdasarkan observasi dilapangan bertempat di TK Al-Hilal peneliti menemukan permasalahan kemampuan menyimak anak khususnya anak usia 4-5 tahun dengan jumlah anak 15 orang dalam kelompok A. Dari 15 orang anak hanya 6,7\% anak yaitu sekitar 1 orang anak yang kemampuan menyimaknya berkembang sesuai harapan dan Mulai Berkembang sekitar 11 anak mencapai 73,3\%. Hal ini dapat terlihat dari keseharian anak didalam kelas saat guru membacakan sebuah cerita, anak- anak tidak memperhatikan, karena anak lebih banyak berbicara dengan temannya dari pada menyimak cerita guru dan lebih senang bermain sendiri pada saat guru bercerita. Proses belajar mengajar yang terjadi kurang menarik bagi anak karena masih kurang media/alat peraga yang digunakan guru untuk mendukung penjelasan pengajaran yang optimal, selain itu guru yang kurang paham tentang metode bercerita, sehingga kemampuan menyimak anak sangat kurang dalam memperhatikan guru bercerita.

Permasalahan diatas merupakan dasar yang sangat menarik untuk dikaji guna mendapatkana perbaikan terhadap pelaksanaan pembelajaran yang menarik bagi anak khususnya dalam pembelajaran menyimak melalui bercerita.

Berdasarkan uraian diatas, maka perlu diadakan penelitian dengan judul "Meningkatan Kemampuan Menyimak Anak Usia 4-5 Tahun Melalui Metode Bercerita Di TK Al-Hilal Tahun Pelajaran 2018/2019.

\section{Rumusan Masalah}

Berdasarkan latar belakang diatas maka rumusan masalah ini adalah: Bagaimana meningkatkan kemampuan menyimak anak usia 4-5 tahun melalui metode bercerita di TK Al-Hilal Tahun Pelajaran 2018/2019

\section{Tujuan Perbaikan Tujuan Umum}

Adapun tujuan perbaikan secara umum adalah untuk mengetahui peningkatan perkembangan menyimak anak usia 4-5 tahun melalui kegiatan bercerita di TK Al-Hilal Tahun pelajaran 2018/2019

\section{Tujuan Khusus}

Adapun tujuan secara khusus dari penelitian ini adalah :

a. Untuk memperoleh gambaran perkembangan kemapuan menyimak anak usia 4-5 tahun melalui kegiatan bercerita.

b. Untuk mengetahui efektifitas kegiatan bercerita dalam rangka meningkatkan kemampuan menyimak anak di TK A usia 4-5 tahun.

\section{Manfaat Perbaikan}

Manfaat secara teoritis yaitu :

a. Penelitian ini senantiasa menjadi wahana untuk meningkatkan pengetahuan dan keterampilan guru dalam meningkatkan kemampuan menyimak pada anak melalui kegiatan bercerita.

b. Penelitian ini senantiasa menjadi wahana untuk menerapkan kemampuan penelitian ilmiah dalam mengkaji permasalahan dibidang pendidikan pada jenjang Tamana kanak-kanak (TK). 
Manfaat Penelitian secara praktis :

a. Bagi guru, hasil penelitian ini diharapkan sebagai informasi tentang cara meningkatkan kemampuan menyimak melalui metode bercerita pada anak usia 4-5 tahun.

b. Bagi siswa, untuk dapat menciptakan generasi penerus bangsa yang memiliki pertumbuhan baik fisik maupun praktis yang unggul dan memiliki motivasi untuk mencapai prestasi yang tinggi.

c. Bagi lembaga, menjadi masukan yang baik dalam pengambilan kebijakan khususnya dalam usaha meningkatkan kemampuan menyimak pada anak melalui kegiatan bercerita.

\section{METODE PENELITIAN}

\section{Subjek Penelitian}

1. Nama Lokasi

Penelitian ini dilakukan di TK Al-Hilal yang beralamat Jalan Panjitilar Negarai No. 105 Sekarbela Mataram berdiri pada tahun 2006.

2. Kelompok : TK A

3. Tema/Sub Tema :
a. Siklus I, Binatang/Binatang Ternak
b. Siklus II, Binatang/Binatang yang dapat terbang (kupu-kupu)

4. Waktu
a. Siklus I, Tanggal 11 s/d 15 Maret 2019
b. Siklus II, Tanggal 25 s/d 29 Maret 2019

5. Karakteristik anak

Karakteristik kemampuan bahasa anak usia 4-5 tahun menurut Dhieni (2005: 9.4) anak sudah mampu mengucapkan lebih dari 2500 kata. lingkup kosa kata yang dapat diucapkan anak menyangkut warna, ukuran, bentuk, rasa, kecepatan, suhu, perbedaan, perbandingan jarak, permukaan (kasar-halus). Dapat berpartisipasi dalam suatu percakapan, anak dapat mendengarkan orang lain berbicara dan menanggapi pembicaraan orang tersebut. Percakapan dilakukan anak usia 4-5 tahun telah menyangkut berbagai komentar terhadap apa yang dilakukan oleh dirinya sendiri dan orang lain. Prosedur Kegiatan Pengembangan

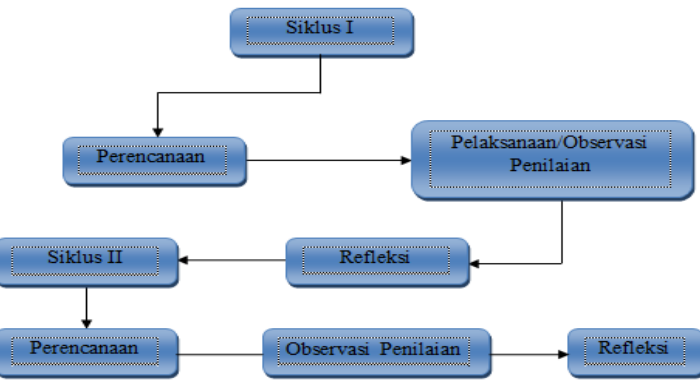

\section{Pengumpulan Data}

Rencana Pengamatan dan

Rencana Pengamatan

Selama pelaksanaan penelitian pengamatan atau observasi, hal yang diamati adalah aktivitas-aktivitas anak yang tampak selamaproses pembelajaran berlangsung dan semuanya di catat dalam lembar observasi yang telah disiapkan, evaluasi dilakukan pada setiap akhir satu siklus. Kegiatan yang dilakukan paa rencana pengamatan ini adalah:

1. Melihat kekurangan dan proses belajar mengajar serta aktivitas anak dengan menggunkan lembar observasi.

2. Melaksanakan perbaikan untuk siklus berikutnya.

\section{Cara Pengumpulan Data}

Dalam penelitian, pengumpulan data merupakan bagian yang penting bahkan merupakan satu keharusan. pada umumnya data yang digunkan adalaha dat primer dan skunder. Data primer adalah data yang diperoleh secara langsung atau data dari sumber pertama, sedangkan data skunder adalah data yang diperoleh secara tidak langsung.

Untuk mendapatkan data dalam penelitian ini tehnik yang dipergunakan adalah tehnik observasi yaitu salah atu tehnik pengumpulan data yang digunakan untuk mendapatkan informasi dengan cara mengamati perilaku dalam situasi tertentu.

Rencana Refleksi

Sesuai dengan permasalahan dan tujuan penelitian, maka refleksi dilakukan pada akhir siklus. Pada tahap ini peneliti mengkaji pelaksanaan dan hasil yang diperoleh dalam pemberin tindakan kelas pada suatu siklus baik itu berupa kekuatan 
ataupun kelemahan dari proses pembelajaran yang sudah dilakukan.

\section{HASIL DAN PEMBAHASAN Pembahasan Tiap Siklus}

Berdasarkan temuan-temuan dari kegiatan pembelajaran selama siklus I dan siklus II, yang terdiri dari sepuluh kali tampilan yang baik dan berkaitan dengan hasil belajar anak maupun tampilan guru dalam proses pembelajaran di setiap siklus, sehingga memperoleh data sebagai berikut :

\section{Siklus I}

Hasil belajar anak

Pada Siklus I ini penelitian yang dilakukan pada tanggal 22-26 Oktober 2018, dari siklus ini diperoleh data hasil belajar anak dalam perkembangan kemampuan menyimak anak sebelum menentukan kriteria pedoman penelitian terlebih dahulu peneliti menentukan skor apabila indikator sudah tampak penskorannya adalah sebagai berikut :

a. Skor 4 (BSB) diberikan apabila anak telah bisa melaksanakan semua indikator dan perkembangan sesuai harapan.

b. Skor $3(\mathrm{BSH})$ diberikan apabila anak bisa melaksanakan indikator dan berkembang.

c. Skor 2 (MB) diberikan apabila anak mulai berkembang dan belum bisa menyelesaikan tiap indikator.

d. Skor 1 (BB) diberikan apabila anak sama sekali tidak bisa melakukan tiap indikator.

Siklus I dilaksanakan pada tanggal 2226 Oktober 2018 di TK Al-Hilal . Subyek peneliti adalah siswa yang berada pada rentang usia 4-5 tahun berjumlah 15 orang anak yang terdiri dari 8 siswa perempuan dan 7 siswa laki-laki.

Berdasarkan penelitian yang dilakukan maka diperoleh hasil terhadap pelaksanaan kegiatan menyimak melalui bercerita yang dilaksanakan dalam tahap Siklus I.

Instrumen penelitian Hasil Pengamatan Kemampuan Menyimak Anak Siklus I

\begin{tabular}{|c|c|c|c|}
\hline No. & Kategori & Jumlah Anak & Persentase (\%) \\
\hline 1 & BB & $\frac{3}{15} \times 100 \%$ & $20,0 \%$ \\
\hline 2 & MB & $\frac{11}{15} \times 100 \%$ & $73,3 \%$ \\
\hline 3 & BSH & $\frac{1}{15} \times 100 \%$ & $6,7 \%$ \\
\hline 4 & BSB & & \\
\hline
\end{tabular}

Jurnal Ilmiah Mandala Education
Dari tabel hasil pengamatan Siklus I, dapat dilihat dari penilaian menyimak anak bahwa anak yang dapat menyimak melalui metode Bercerita 11 anak $(73,3 \%)$ anak yang mulai berkembang, dan 4 anak $(20,0 \%)$ anak Belum Berkembang, sedangkan 1 anak $(6,7 \%)$ Berkembang sesuai harapan.

Grafik Pencapaian menyimak anak Siklus I

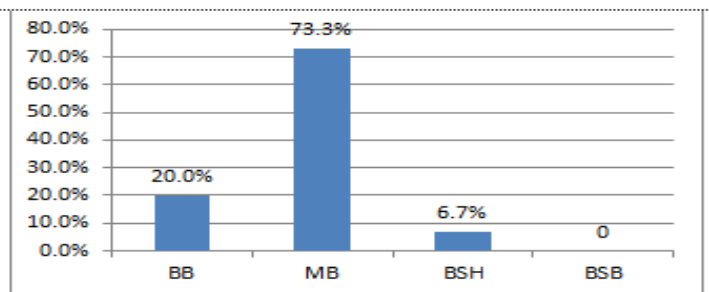

Dari grafik di atas dapat dilihat dari prosentase pencapaian kemampuan kemampuan menyimak anak untuk di kategorikan Belum Berkembang 20,0\%, Mulai Berkembang $73.3 \%$, Berkembang sesuai harapan 6,7\%, Berkembang Sangat Baik 0\%, dapat disimpulkan dari RKH 5 untuk dikategorikan yang paling menonjol kemampuan menyimaknya adalah Mulai Berkembang 73,3\%.

Dengan demikian dapat ditarik kesimpulan bahwa kemampuan menyimak anak melalui metode bercerita Masih Mulai Berkembang.

Dari data tersebut dapat dilihat bahwa perkembangan kemampuan menyimak anak masih belum mencapai target, karena dilihat dari indikator pencapaian perkembangan kemampuan menyimak anak yang digunakan dalam penelitian ini adalah $80 \%$.

\section{Siklus II Hasil belajar anak}

Pada Siklus II penelitian yang dilakukan pada tanggal 5-9 November 2018, dari siklus ini data hasil belajar anak dalam hal perkembangan kemampuan menyimak dalam kegiatan bercerita, adapun instrumen penelitian sebagai subjek yang diteliti sehingga memperoleh berapa persen tingkat pencapaian kemampuan menyimak anak melalui metode bercerita.

Hasil Kemampuan Menyimak Anak Siklus II 


\begin{tabular}{|c|c|c|c|}
\hline No. & Kategor & Jumlah Anak & Persentase (\%) \\
\hline 1 & BB & & \\
\hline 2 & MB & $\frac{1}{15} \times 100 \%$ & $6,7 \%$ \\
\hline 3 & BSH & $\frac{12}{15} \times 100 \%$ & $80,0 \%$ \\
\hline 4 & BSB & $\frac{2}{15} \times 100 \%$ & $13,3 \%$ \\
\hline
\end{tabular}

Dari tabel Siklus I dan ke Siklus II terjadi peningkatan yaitu 1 anak Mulai Berkembang $(6,7 \%)$ bertambah menjadi 12 anak Berkembang Sesuai Harapan (80,0\%) sedangkan peningkatan kemampuan menyimak anak terdapat 2 anak Berkembang Sangat Baik (13,3\%). Hal ini terlihat dari hasil penelitian kemampuan menyimak anak melalui metode bercerita Usia 4-5 Tahun di TK Al-Hilal.n

Grafik Kemamuan menyimak anak Siklus II

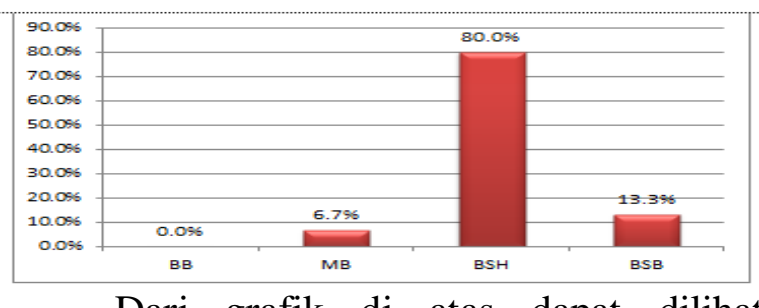

Dari grafik di atas dapat dilihat persentase pencapaian kemampuan menyimak anak pada RKH 10 Mulai Berkembang 1 orang anak $(6,7 \%)$ dan bertambah menjadi 12 anak Berkembang Sesuai Harapan $(80,0 \%)$ dan terus meningkat kemampuan menyimak anak, 2 anak Berkembang Sangat Baik Mencapai (13,3\%).

Pada proses pengembangan Siklus II dapat dilihat bahwa semua anak sudah mencapai target ketercapaian untuk perkembangan kemampuan menyimak. Semua ini tidak terlepas dari usaha guru yang membuat anak lebih tertarik sehingga lebih fokus dalam kegiatan bercerita walaupun tidak ada yang mencapai $100 \%$, akan tetapi berdasarkan hasil yang dicapai menunjukkan hasil yang cukup signifikan dengan indikator pencapaian sebesar $80,0 \%$.

Dari hasil pengamatan dari siklus 1 dan siklus II dengan Siklus 1 menggunakan RKH 5 dan Siklus II menggunakan RKH 5 menjadi $10 \mathrm{RKH}$. Adapun tingkat pencapaian Grafik dari RKH 5 pada siklus I dan RKH 10 Siklus II

Jurnal Ilmiah Mandala Education

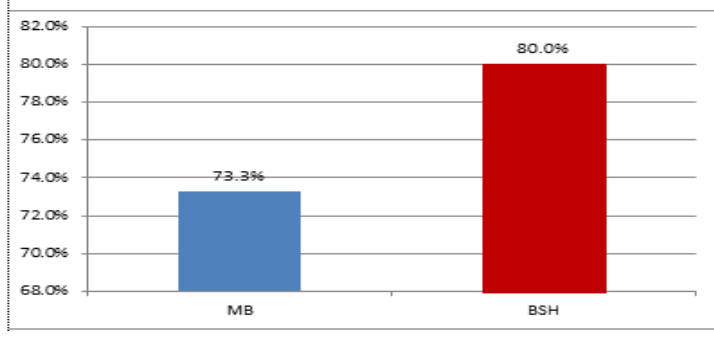

Tampilan RKH 5 Siklus I

Tampilan RKH 10 Siklus II

Dari grafik diatas dapat dijelaskan bahwa persentase penampilan guru mengalami peningkatan dari $73,3 \%$ pada siklus I tampilan RKH 5 meningkatn menjadi $80,0 \%$ pada siklus II tampilan RKH 10 . Hal ini dibuktikan oleh adanya keinginan dan usaha pendidik untuk terus memperbaiki kekurangan-kekurangan selama proses pembelajaran dalam setiap tampilan dan siklus perbaikan. Dengan demikian dapat disimpulkan bahwa, pendidik sudah dapat mengajar dengan baik dan sesuai dengan perencanaan yang dibuatnya, sehingga pelaksanaan pembelajaran di TK Al-Hilal dapat dilakukan dengan baik dalam meningkatan keterampilan menyimak anak melalui metode bercerita di TK Al-Hilal .

Berdasarkan hasil penelitian di atas bahwa menyimak menggunakan metode bercerita dapat meningkatkan perkembangan kemampuan menyimak anak usia 4-5 tahun akan tetapi ada beberapa kriteria yang harus diperhatikan oleh guru atau orang dewasa lainnya dalam memilih dan menyajikan cerita untuk anak menurut Kusmiadi (Jurnal Ilmiah, 2008:2) diantaranya adalah :

1. Cerita harus menarik dan memikat perhatian

2. Cerita yang yang akan disajikan harus sesuai dengan kepribadian anak, gaya dan bakat anak agar menarik perhatian anak dan keterlibatan anak dalam kegiatan bercerita.

3. Cerita disesuaikan dengan usia dan tingkat kemampuan menyimak anak.

4. Cerita cukup pendek dalam rentang waktu jangkauan perhatian anak.

Gordon (1985:325) dalam Kusmiadi (Jurnal Ilmiah, 2008:2) menyebutkan bahwa pendidik dalam bercerita memainkan 
perwatakan tokoh-tokoh dalam dongeng yang disukai anak dan merupakan daya tarik yang bersifat universal.

Berdasarka pendapat tersebut, maka dapat disimpulkan bahwa isi dari cerita yang akan disajikan untuk anak usia dini harus sesuai dengan tahap perkembangan anak, bahasa dan langkah pelaksanaan agar lebih menarik minat anak serta menyenangkan bagi anak. Hal ini sejalan dengan yang dikatakan oleh Tampubolon (1991:50) dalam Dhieni (2009:6.12) bahwa " isi cerita hendaknya sesuai dengan pikiran dan pengalaman anak".

\section{KESIMPULAN}

Berdasarkan hasil analisis data serta pembahasan dari hasil penelitian yang telah dilaksanakan melalui tahap I dan tahap II, maka dapat disimpulan bahwa :

1. Dari hasil proses bercerita membuat anak lebih kreatif dan aktif dalam proses pengembangan kemampuan menyimak. Hal ini terbukti dari hasil observasi pada siklus I dan pada siklus II mengalami peningkatan.

2. Pada Siklus I perkembangan rata-rata kemampuan menyimak anak mencapai 20,0\% (Belum Berkembang) dan hasil ini diperoleh berdasarkan instrumen pengamatan pengembangan kemampuan menyimak anak dan kategori dikatakan belum tercapai (belum ada peningkatan) karena indikator yang digunakan dalam penelitian ini maksimal 80,0\%.

3. Pada Siklus II dimana rata-rata perkembangan kemampuan menyimak anak mencapai 80,0\% (Berkembang Sesuai Harapan) dengan kategori sangat baik perkembangannya dan mengalami peningkatan yang cukup signifikan.

4. Meningkatkan kemampuan menyimak melalui metode bercerita dapat tercapai optimal melalui langkah-langkah bercerita antara lain: Menentukan topik, menyusun kerangka cerita, mengembangkan kerangka cerita, menyusun teks cerita, keruntutan cerita, intonasi, lafal dansuara harus diperhatikan, menyediakan media yang menarik yang sesuai dengan cerita, menggunakan efek suara yang sesuai dengan cerita.

Dengan kata lain bahwa melalui metode bercerita akan meningkatkan perkembangan kemampuan menyimak anak. Tetapi harus disesuaikan dengan cerita dan penambahan setting suara sangat mempengaruhi dalam meningkatkan kemampuan menyimak anak tentunya dengan langkah-langkah yang baik dan sesuai.

\section{SARAN}

Berdasarkan hasil penelitian tentang pengembangan kemampuan menyimak anak, maka dengan ini penulis menyarankan :

1. Bagi kepala sekolah agar selalu menuntun, mengawasi dan mendorong para guru dalam meningkatkan kualitas belajar mengajar melalui peningkatan kemampuan dalam menggunakan metode dan pendekatan mengajar yang tepat sesuai dengan perkembangan anak, sehingga dapat meningkatkan daya serap anak dalam setiap perkembangan.

2. Sebaiknya ruangan kelas untuk anak usia dini perlu diperluas lagi karena anak pada usia tersebut sangat membutuhkan kebebasan dalam berekspresi baik itu di dalam ruangan maupun di luar ruangan, karena jika ruang kelas terlalu sempit akan menghambat kreatifitas anak dalam berfikir.

3. Kepada guru sebaiknya ketika dalam proses belajar-mengajar pendapatpendapat anak seharusnya diutamakan jangan diabaikan, karena akan membuat anak merasa tidak dihargai pendapatnya dan pada saat bercerita dalam mengembangkan menyimak anak sebaiknya menggunakan media-media yang menarik seperti media boneka tangan, boneka jari, celemek ajaib, panggung boneka.

\section{DAFTAR PUSTAKA}

AECT (Association of Education and Communication Technology). 1977. Pengertian Media.

Dhieni Nurbiana, Fridani Lara, Yarmi Gusti, dan Kusniaty Nany. (2007). Metode 
Pengembangan Bahasa. Jakarta:

Universitas Terbuka

Musfiroh. (2005). Pembelajaran dengan

Metode Bercerita. Jakarta: Rineka

Cipta

Peraturan Menteri Pendidikan Republik

Indonesia No 58 Tahun 2009

Tentang Standar Pendidikan Anak

Usia Dini. Jakarta

Subyakto. (2005). Upaya Meningkatkan Kemampuan Menyimak Pembelajar. Jakarta: Tugu Publisher.

Sugiyono, (2009). Metode Penelitian Kuantitatif Kualitatif dan R\&D /ABT, Jakarta : CV Alfabeta.

Suhartono. (2005). Pengembangan Keterampilan Menyimak Anak Usia Dini. Jakarta: Depdiknas.

Suyanto, Slamet. (2005). Pembelajaran Untuk AnakTK. Jakarta: Depdiknas

Tampubolon.(1991). Menegmbangkan minat dan membaca pada anak. Bandung. Angkasa.

Tarigan, Henry Guntur. (1986). Menyimak Sebagai Suatu Keterampilan Berbahasa. Bandung: Angkasa.

Tita PKP PG PAUD, 2017. Panduan Kemantapan Kemampuan Keprofesional, Tangerang, Universitas Terbuka.

Toha Anggoro,M, dkk., (2010). Metode Penelitian Edisi 2, Jakarta : Universitas Terbuka.

Wardhani, IGAK dan Wihardit, K. 2017. Penelitian Tindakan Kelas, Tangerang Selatan, Universitas Terbuka.

http://prihadipati.blogspot.com/ diakses 22 Oktober 2018 tentang Mimik dan Ekspresi. 